\title{
Effects of Basic Fibroblast Growth Factor on Bone Formation In Vitro
}

Emesto Canalis, Michael Centrella, and Thomas McCarthy

Department of Medicine (Endocrine Section) and Research Laboratory, Saint Francis Hospital and Medical Center, Hartford, Connecticut 06105; and The University of Connecticut Health Center, Farmington, Connecticut 06032

\begin{abstract}
Basic fibroblast growth factor (bFGF) was studied for its effects on bone formation in cultured rat calvariae. bFGF at 0.1-100 $\mathrm{ng} / \mathrm{ml}$ stimulated $\left[{ }^{3} \mathrm{H}\right]$ thymidine incorporation into DNA by up to 4.4-fold. bFGF also increased the number of colcemid-induced metaphase arrested cells and the DNA content. Transient $(24 \mathrm{~h})$ treatment with bFGF enhanced $\left[{ }^{3} \mathrm{H}\right]-$ proline incorporation into collagen $24-48 \mathrm{~h}$ after the factor was removed; this effect was DNA synthesis dependent and blocked by hydroxyurea. The collagen stimulated by bFGF was type I, and this effect was observed primarily in the periosteum-free bone. In contrast, continuous treatment with bFGF for 24-96 $\mathrm{h}$ inhibited ${ }^{3} \mathrm{H}$ ]proline incorporation into type I collagen. bFGF did not alter collagen degradation. In conclusion, bFGF stimulates calvarial DNA synthesis, which causes an increased number of collagen-synthesizing cells, but bFGF has a direct inhibitory effect on collagen synthesis.
\end{abstract}

\section{Introduction}

Growth factors are mitogens with important effects on cell function. Initially, growth factors were considered to act as systemic agents, but recent information indicates that they are synthesized by multiple tissues, where they appear to act as autocrine or paracrine regulators of cell growth (1). Fibroblast growth factors (FGFs) ${ }^{1}$ are polypeptides originally isolated from the central nervous system, but also found in a variety of tissues including bone (2-7). Two forms of FGFs have been described: acidic (aFGF) and basic (bFGF); they have $55 \%$ homology in their amino acid sequence, have similar biological effects, and interact with the same cell receptors $(3,8,9)$.

The skeletal tissue is a rich source of growth factors, and the bone matrix has been shown to contain aFGF and bFGF (7). This suggests that aFGF and bFGF are either preferentially trapped by the bone matrix or are synthesized by skeletal cells; in either case, they may play a role in the local regulation of

Address correspondence and reprint requests to Dr Canalis, Saint Francis Hospital and Medical Center, 114 Woodland St., Hartford, CT 06105.

Received for publication 10 September 1987 and in revised form 30 November 1987.

1. Abbreviations used in this paper: aFGF, acidic FGF; bFGF, basic FGF; BGJ, Biggers Gwatkin medium modified by Fitton Jackson; CDP, collagenase-digestible protein; ECGF, endothelial cell growth factor; FGF, fibroblast growth factor; NCP, noncollagen protein; PCS, percent collagen synthesized.

J. Clin. Invest.

(C) The American Society for Clinical Investigation, Inc.

$0021-9738 / 88 / 05 / 1572 / 06 \quad \$ 2.00$

Volume 81, May 1988, 1572-1577 bone remodeling. Endothelial cell growth factor (ECGF), a form of aFGF, was shown to stimulate bone cell replication and, as a result, bone collagen synthesis, but the effects of bFGF on bone formation have not been reported (10). Studies using partially purified preparations of FGF indicated that it was mitogenic for bone cultures, but pure preparations of recombinant bFGF have not been tested, and its function in the process of bone remodeling has not been defined (11). Since both aFGF and bFGF stimulate endothelial cell replication and neovascularization $(8,12)$, the additional demonstration of an effect on bone formation could provide useful information to our understanding of bone repair.

The present studies were undertaken to characterize the role of bFGF in bone formation. For this purpose, we assessed the direct effects of recombinant bFGF on bone cell replication, collagen, and noncollagen protein (NCP) synthesis, and collagen degradation in rat calvarial cultures.

\section{Methods}

\section{Culture model}

The method used to study effects on bone formation was previously described in detail (13). One or two half calvariae from 21-d fetal rats were cultured in sterile $25-\mathrm{ml}$ flasks containing $2 \mathrm{ml}$ of modified Biggers Gwatkin medium modified by Fitton Jackson (BGJ) medium supplemented with $1 \mathrm{mM}$ unlabeled proline (except for collagen degradation experiments), $0.1 \mathrm{mM}$ thymidine, and heat-inactivated $\left(60^{\circ} \mathrm{C} / 2\right.$ h) BSA ( $4 \mathrm{mg} / \mathrm{ml}$, Armour Pharmaceutical Co, Kankakee, IL), but no serum. The BSA preparation used was fraction $\mathrm{V}$ from serum, and analysis by polyacrylamide gel electrophoresis and silver staining revealed one protein band. The flasks were gassed with $5 \% \mathrm{CO}_{2}$ in air, sealed, and placed in a continuously shaking water bath at $37^{\circ} \mathrm{C}$ for periods of 24-96 h.

Recombinant bovine bFGF, kindly provided by Dr. G. M. Fox (Amgen, Thousand Oaks, CA), was stored in $20 \mathrm{mM}$ sodium citrate, $100 \mathrm{mM}$ sodium chloride, and $0.1 \% \mathrm{BSA}$ at $-80^{\circ} \mathrm{C}$, and diluted 1:6,000 or greater in BGJ; an equal amount of solvent was added to control cultures. Hydroxyurea (Sigma Chemical Co., St. Louis, MO) and sodium heparin (Invenex Laboratories, Melrose Park, IL) were added directly to BGJ medium and indomethacin (Sigma Chemical Co.) was dissolved in absolute ethanol and diluted 1:10,000 in BGJ medium; an equal amount of alcohol was added to control cultures. Calvariae were continuously exposed to the agents studied unless specified otherwise.

\section{DNA synthesis}

DNA synthesis was studied by examining effects on the incorporation of $\left[{ }^{3} \mathrm{H}\right]$ thymidine and on total DNA content.

DNA labeling. [methyl $-{ }^{3} \mathrm{H}$ ] Thymidine $(5 \mu \mathrm{Ci} / \mathrm{ml}, 62 \mathrm{Ci} / \mathrm{mmol} \mathrm{sp}$ act; ICN Radiochemicals, Irvine, $C A$ ) was added during the last $60 \mathrm{~min}$ of the culture period. Calvariae were extracted with cold 5\% TCA, acetone, and ether; the bones were then dried and weighed and the incorporated radioactivity was determined after digesting them with NCS tissue solubilizer (Amersham Corp., Arlington Heights, IL). Data are expressed as disintegrations per minute per microgram dry weight or as percent of control after dry weight correction. 
DNA content. To measure total DNA content, calvariae were homogenized, extracted with $5 \%$ TCA and $10 \mathrm{mM}$ potassium acetate in absolute ethanol, and dried. DNA was measured according to a modification of the fluorometric method of Kissane and Robbins (14). Data are expressed as micrograms DNA per half calvaria.

\section{Histology and mitotic index}

To study effects on cell mitosis, calvariae were cultured and $N$-deacetyl- $N$-methylcolchicine (Colcemid; $4 \times 10^{-6} \mathrm{M}$; Gibco, Grand Island, NY) was added for the last $3 \mathrm{~h}$ of the culture period. Calvariae were fixed in neutral formalin, embedded in paraffin, stained with hematoxylin-eosin, and sections examined at a 250-400 magnification. Metaphase-arrested cells were counted in at least two random crosssections taken from each of four to five control and treated bone explants. Data are expressed as number of mitoses per section of half calvaria.

\section{Collagen and NCP synthesis}

Effects on newly synthesized collagen were determined by studying the incorporation of $\left[2,3-{ }^{3} \mathrm{H}\right]$ proline $(25-40 \mathrm{Ci} / \mathrm{mmol} \mathrm{sp}$ act, New England Nuclear, Boston, MA) into total collagen and into type I collagen. Labeled proline $(5 \mu \mathrm{Ci} / \mathrm{ml}$ for total and $50 \mu \mathrm{Ci} / \mathrm{ml}$ for type I collagen experiments) was added for the last $2 \mathrm{~h}$ of the culture period.

Total collagen synthesis. Calvariae were extracted as described for DNA labeling and homogenized in $0.5 \mathrm{M}$ acetic acid. An aliquot was incubated with repurified bacterial collagenase (Cooper Biomedical, Malvern, PA), the labeled proline incorporated into collagenase-digestible protein (CDP), and NCP was measured according to the method of Peterkofsky and Diegelmann (15). Data are expressed as disintegrations per minute dry weight or as percent of control after dry weight correction. Percent collagen synthesis was calculated after multiplying NCP by 5.4 to correct for the relative abundance of proline in collagen and NCP (16).

Type I collagen synthesis. Calvariae were rinsed with saline $(\mathrm{NaCl}$, $9 \mathrm{~g} /$ liter), homogenized as a pool in $0.5 \mathrm{M}$ acetic acid, digested with pepsin $(1 \mathrm{mg} / \mathrm{ml}$, Sigma Chemical Co. $)$ over a $12-16-\mathrm{h}$ period at $4^{\circ} \mathrm{C}$, and neutralized with sodium hydroxide. An aliquot representing onehalf calvaria and a radioactive type I collagen standard were dissolved in sample buffer, and the collagen chains were separated on a $6 \%$ polyacrylamide gel according to a modification of the method described by Sykes et al. (17). 2-Mercaptoethanol was applied to half of the samples 60 min after the electrophoresis was started (reduced collagen) while the other half were not treated (unreduced collagen). At the completion of the electrophoresis, the gels were fixed and the protein profiles were displayed by fluorography.

\section{Collagen degradation}

To study effects on collagen degradation, calvariae were cultured in control medium in the absence of unlabeled proline and treated with $\left[{ }^{3} \mathrm{H}\right]$ proline, $5 \mu \mathrm{Ci} / \mathrm{ml}$, for a $24-\mathrm{h}$ period. Bones were washed with BGJ medium containing $10 \mathrm{mM}$ proline for $1 \mathrm{~h}$ and transferred to either control or bFGF-containing medium for a 6-, 24-, or 48-h "chase period." At the end of the experiment, calvariae were washed with saline, and bone and medium samples were stored at $-80^{\circ} \mathrm{C}$. Calvariae were homogenized in $0.5 \mathrm{M}$ acetic acid and an aliquot of this homogenate and of the respective culture medium was hydrolyzed in $6 \mathrm{~N} \mathrm{HCl}$ at $107^{\circ} \mathrm{C}$ for $24 \mathrm{~h}$. The samples were dried, derivatized with phenylisothiocyanate, and the $\left[{ }^{3} \mathrm{H}\right]$ proline (used for the labeling) and $\left[{ }^{3} \mathrm{H}\right]-$ hydroxyproline (representing newly labeled collagen) separated by reverse-phase high pressure liquid chromatography using an amino acid analysis PICO-TAG column (Waters Assoc., Div. of Millipore Corp., Milford, MA) and an acetonitrile gradient $(10) .\left[{ }^{3} \mathrm{H}\right] \mathrm{Hydroxyproline}$ and $\left[{ }^{3} \mathrm{H}\right]$ proline eluted with 19 and $26 \%$ acetonitrile, respectively; their separation was nearly complete and the amount of $\left[{ }^{3} \mathrm{H}\right]$ proline eluting as $\left[{ }^{3} \mathrm{H}\right]$ hydroxyproline was $<6 \%$. This was corrected by constructing a standard curve of $\left[{ }^{3} \mathrm{H}\right]$ proline "spillover" into the $\left[{ }^{3} \mathrm{H}\right]$ hydroxyproline peak by using increasing amounts of $\left[{ }^{3} \mathrm{H}\right]$ proline. Recovery of radioactively labeled and of unlabeled added hydroxyproline was
70-100\%. Data are expressed as picomoles of total $\left[{ }^{3} \mathrm{H}\right]$ hydroxyproline present in the medium, and as percent of $\left[{ }^{3} \mathrm{H}\right]$ hydroxyproline released from bone to the culture medium.

\section{Effects on periosteum and periosteum-free calvaria}

These experiments were performed to compare effects on periosteal tissue, rich in fibroblasts and osteoprogenitor cells, with those on the central calvaria, which is rich in osteoblasts $(18,19)$. Intact bones were cultured, and $\left[{ }^{3} \mathrm{H}\right]$ thymidine or $\left[{ }^{3} \mathrm{H}\right]$ proline was added for the last 60 or $120 \mathrm{~min}$ of the incubation period, respectively. Calvariae were washed with saline and the periosteum was removed from the superior and inferior surfaces of the bone with a scalpel blade. The incorporation of $\left[{ }^{3} \mathrm{H}\right]$ thymidine into DNA and of $\left[{ }^{3} \mathrm{H}\right]$ proline into CDP and NCP were independently determined in the periosteum and in the central bone or periosteum-free calvaria. Data are expressed as disintegrations per minute per half calvaria.

\section{Statistical methods}

Data are expressed as mean and standard error (SE) of the mean. Statistical differences were analyzed using Student's $t$ test.

\section{Results}

DNA synthesis and cell replication. bFGF caused a dose-related stimulation on the incorporation of $\left[{ }^{3} \mathrm{H}\right]$ thymidine into acid-precipitable material (DNA) in calvariae treated for $24 \mathrm{~h}$ (Fig. 1). The effect was observed at concentrations as low as 0.1 $\mathrm{ng} / \mathrm{ml}$, and at $100 \mathrm{ng} / \mathrm{ml}$ bFGF increased DNA labeling by 4.4-fold. Treatment with bFGF $(10 \mathrm{ng} / \mathrm{ml})$ for $24 \mathrm{~h}$ increased calvarial DNA from a control value of $5.7 \pm 0.7$ to $10.4 \pm 1.5$ $\mu \mathrm{g} /$ half calvaria (mean $\pm \mathrm{SE}, n=6)(P<0.05)$. bFGF also increased the number of metaphase-arrested cells after colcemid treatment, an effect that was of greater magnitude in the precursor cell-rich periosteum than in the osteoblast-rich central bone (Table I). When calvariae were exposed to bFGF $(100 \mathrm{ng} / \mathrm{ml})$ for $2 \mathrm{~h}$ and transferred to control medium for the rest of a 24-h culture, DNA labeling was increased by $3.05 \pm 0.17$-fold (mean $\pm \mathrm{SE}, n=5$ ). This effect was virtually identical to that observed in bones treated continuously with bFGF for $24 \mathrm{~h}$, which, in the same experiment, increased DNA labeling by $3.02 \pm 0.19$-fold. The effect of bFGF on DNA synthesis was sustained for periods of up to $96 \mathrm{~h}$, and continuous treatment with bFGF at doses as low as $0.1 \mathrm{ng} / \mathrm{ml}$ for $96 \mathrm{~h}$ stimulated $\left[{ }^{3} \mathrm{H}\right]$ thymidine incorporation into DNA, an effect that was maximal at $1 \mathrm{ng} / \mathrm{ml}$ (Table II). Treatment with bFGF for $96 \mathrm{~h}$ at $1-100 \mathrm{ng} / \mathrm{ml}$ also increased the calvarial DNA content.

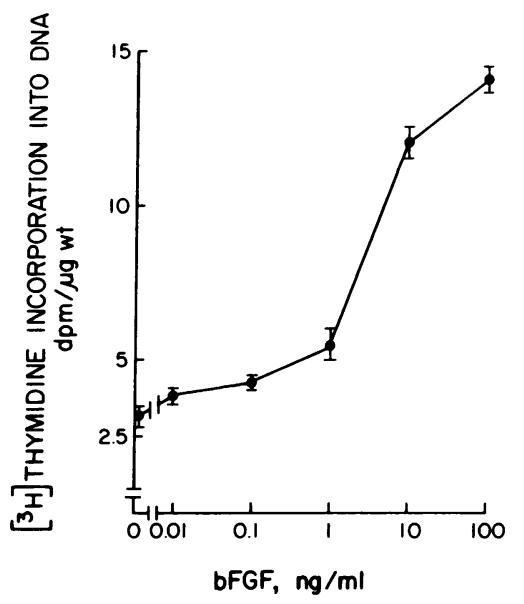

Figure 1. Effect of bFGF on $\left[{ }^{3} \mathrm{H}\right]-$ thymidine incorporation into acid-precipitable material (DNA) in cultured calvariae. Symbols and their vertical lines represent mean values and SE for six half calvariae cultured for $24 \mathrm{~h}$ in the continuous presence of bFGF. Values for bFGF at $0.1-100 \mathrm{ng} / \mathrm{ml}$ are significantly different from control, $P<0.05$. 
Table I. Effect of bFGF on Mitotic Index in Calvariae Cultured for $24 \mathrm{~h}$

\begin{tabular}{lccc}
\hline & \multicolumn{3}{c}{ Mitotic index } \\
\cline { 2 - 4 } \multicolumn{1}{c}{ Treatment } & Total & Periosteum & Central bone \\
\hline Control & $4.5 \pm 0.5$ & $2.1 \pm 0.4$ & $2.4 \pm 0.2$ \\
bFGF $(0.1 \mathrm{ng} / \mathrm{ml})$ & $5.5 \pm 0.8$ & $3.6 \pm 0.4^{*}$ & $1.9 \pm 0.5$ \\
bFGF $(1 \mathrm{ng} / \mathrm{ml})$ & $10.5 \pm 0.5^{*}$ & $8.0 \pm 0.3^{*}$ & $2.5 \pm 0.4$ \\
bFGF $(10 \mathrm{ng} / \mathrm{ml})$ & $15.3 \pm 1.9^{*}$ & $11.3 \pm 2.1^{*}$ & $4.0 \pm 0.4^{*}$ \\
bFGF $(100 \mathrm{ng} / \mathrm{ml})$ & $15.1 \pm 2.8^{*}$ & $10.0 \pm 2.1^{*}$ & $5.1 \pm 0.6^{*}$
\end{tabular}

Values are means \pm SE for five half calvariae cultured for $24 \mathrm{~h}$ in the continuous presence or absence of bFGF and treated with colcemid for the last $3 \mathrm{~h}$ of the incubation. Each calvaria was processed as described in Methods and the number of cells arrested in metaphase counted in two or more random sections for each bone. Data are expressed as number of cells arrested in metaphase per calvarial section and their distribution in the periosteum and central bone.

* Significantly different from control, $P<0.05$.

Collagen and NCP synthesis and collagen degradation. Continuous treatment with bFGF for a 24-h period decreased the incorporation of $\left[{ }^{3} \mathrm{H}\right]$ proline into CDP and increased the labeling of NCP, so that the percent of collagen synthesized (PCS) was decreased (Table III). In contrast to this inhibitory effect, when calvariae were treated with bFGF for $24 \mathrm{~h}$ and transferred to control (bFGF-free) medium for a period of 24 or $48 \mathrm{~h}$ (total culture time 48 or $72 \mathrm{~h}$ ), an increase in collagen synthesis was observed (Table III). During this period of time the effect of bFGF on DNA synthesis rates and DNA content declined, but did not disappear. The DNA content in calvariae transiently exposed to bFGF $(10 \mathrm{ng} / \mathrm{ml}$ for $24 \mathrm{~h})$ and cultured for an additional 48 -h period was $9.1 \pm 1.1 \mu \mathrm{g} / \mathrm{half}$ calvaria (mean $\pm \mathrm{SE}, n=6$ ), while in calvariae cultured in control medium for $72 \mathrm{~h}$ it was $4.5 \pm 0.5 \mu \mathrm{g} / \mathrm{half}$ calvaria $(P<0.05)$. The stimulatory effect of bFGF on collagen synthesis was secondary to its mitogenic effect. In an experiment where bFGF at 10 $\mathrm{ng} / \mathrm{ml}$ increased DNA synthesis $(24 \mathrm{~h}$ after exposure to the agent) by $3.16 \pm 0.12$-fold (mean $\pm \mathrm{SE}, n=6, P<0.05$ ), and collagen synthesis ( $48 \mathrm{~h}$ after removal of the agent) by $1.42 \pm 0.09$-fold $(P<0.05)$, hydroxyurea at $1 \mathrm{mM}$ abolished the

Table II. Effect of bFGF on DNA Synthesis Rates and on DNA Content in Calvariae Cultured for $96 \mathrm{~h}$

\begin{tabular}{lcc}
\hline \multicolumn{1}{c}{ Treatment } & DNA synthesis & DNA content \\
\hline & $d p m / \mu g$ wt & $\mu g /$ half calvaria \\
Control & $3.0 \pm 0.2$ & $7.0 \pm 0.4$ \\
bFGF $(0.01 \mathrm{ng} / \mathrm{ml})$ & $3.2 \pm 0.3$ & $\mathrm{ND}$ \\
bFGF $(0.1 \mathrm{ng} / \mathrm{ml})$ & $5.3 \pm 0.4^{*}$ & $5.9 \pm 0.4$ \\
bFGF $(1 \mathrm{ng} / \mathrm{ml})$ & $10.2 \pm 1.1^{*}$ & $10.4 \pm 0.5^{*}$ \\
bFGF $(10 \mathrm{ng} / \mathrm{ml})$ & $10.4 \pm 0.6^{*}$ & $13.8 \pm 1.3^{*}$ \\
bFGF $(100 \mathrm{ng} / \mathrm{ml})$ & $11.3 \pm 0.5^{*}$ & $12.9 \pm 0.6^{*}$ \\
\hline
\end{tabular}

Values represent bFGF effect on the 1-h incorporation of $\left[{ }^{3} \mathrm{H}\right]$ thymidine into acid-precipitable material and on DNA content in calvariae cultured and continuously treated for $96 \mathrm{~h}$. Values are means \pm SE for six half calvariae.

* Significantly different from control, $P<0.05$.
Table III. Effect of Transient ( $24 h$ ) bFGF Treatment on DNA and Collagen Synthesis Rates in Calvariae Cultured for 24-72 $h$

\begin{tabular}{lcccc}
\hline \multicolumn{1}{c}{ Treatment } & DNA & CDP & NCP & PCS \\
\hline & & $d p m / \mu g w t$ & & $\%$ \\
24-h culture & & & & \\
0-24 $\mathrm{h}$ & & & & \\
$\quad$ Control & $4.9 \pm 0.4$ & $41 \pm 3$ & $48 \pm 2$ & $13.9 \pm 1.0$ \\
$\quad$ bFGF & $17.4 \pm 0.4^{*}$ & $33 \pm 2^{*}$ & $61 \pm 5^{*}$ & $9.3 \pm 0.7^{*}$ \\
48-h culture & & & & \\
0-24 h to 24-48 h & & & & \\
$\quad$ Control to control & $3.1 \pm 0.2$ & $33 \pm 3$ & $42 \pm 3$ & $12.5 \pm 0.5$ \\
$\quad$ bFGF to control & $4.8 \pm 0.6^{*}$ & $45 \pm 3^{*}$ & $62 \pm 1^{*}$ & $11.8 \pm 0.6$ \\
72-h culture & & & & \\
0-24 h to 24-72 h & & & & \\
Control to control & $4.2 \pm 0.3$ & $46 \pm 4$ & $57 \pm 4$ & $13.0 \pm 0.7$ \\
bFGF to control & $8.5 \pm 0.6^{*}$ & $74 \pm 7^{*}$ & $68 \pm 7$ & $16.7 \pm 0.4^{*}$ \\
& & & &
\end{tabular}

Values represent the 24-h effect of bFGF, $10 \mathrm{ng} / \mathrm{ml}$, and the effect of its transient treatment on $\left[{ }^{3} \mathrm{H}\right]$ thymidine incorporation into acid-precipitable material (DNA), on $\left[{ }^{3} \mathrm{H}\right]$ proline incorporation into CDP and NCP and on the PCS. Calvariae were treated only for the first 24 $h$ of culture and transferred to control medium for the remainder of the incubation as indicated. Values are means \pm SE for six half calvariae cultured for 24-72 $\mathrm{h}$.

* Significantly different from control, $P<0.05$.

bFGF effect on DNA synthesis and prevented its stimulatory effect on collagen synthesis, which was only $1.08 \pm 0.15$-fold of control. Hydroxyurea also obliterated the stimulation caused by bFGF on NCP synthesis (data not shown).

Nearly all the collagen synthesized by control and treated calvariae co-migrated on gel electrophoresis with type I, and transient exposure to bFGF stimulated type I collagen synthesis without causing detectable changes in other collagen types (Fig. 2). The incorporation of $\left[{ }^{3} \mathrm{H}\right]$ thymidine into DNA and the incorporation of $\left[{ }^{3} \mathrm{H}\right]$ proline into NCP were higher, and

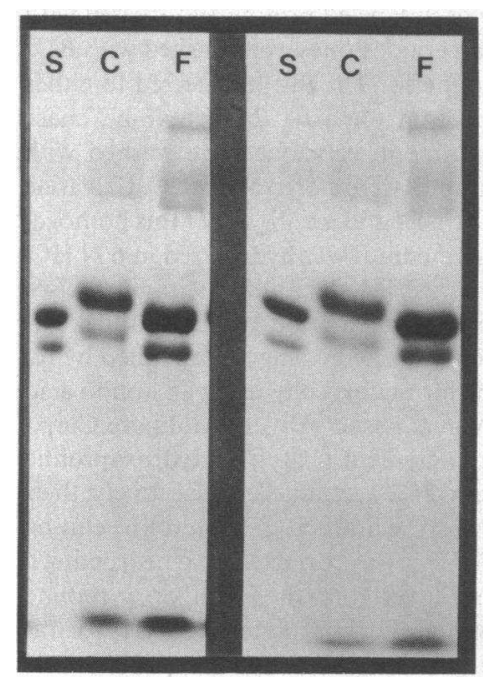

Figure 2. Polyacrylamide gel analysis of newly synthesized calvarial collagen. Bones were treated with bFGF, $10 \mathrm{ng} / \mathrm{ml}$, for $24 \mathrm{~h}$ only, rinsed and transferred to control medium for an additional 48-h period, and compared with control calvariae cultured for $72 \mathrm{~h}$. Newly synthesized $\alpha_{1}$ (I) and $\alpha_{2}$ (I) radioactive collagen chains were separated by interrupted polyacrylamide gel electrophoresis in the absence (left) or presence (right) of 2-mercaptoethanol and were identified by comparison with a radioactive type I collagen standard as shown in lane $S$. Lane $C$ represents onehalf control calvaria and lane $\boldsymbol{F}$ one-half calvaria treated with bFGF. 
Table IV. Stimulatory Effect of bFGF on DNA, Collagen, and NCP Synthesis Rates in Periosteum and Periosteum-free Calvaria

\begin{tabular}{lcccc}
\hline Treatment & DNA & CDP & NCP & PCS \\
& & dpm/bone & \\
Periosteum & & & & \\
Control & $1,630 \pm 120$ & $2,200 \pm 160$ & $4,840 \pm 580$ & $7.7 \pm 0.7$ \\
bFGF & $7,910 \pm 670^{*}$ & $3,020 \pm 250^{*}$ & $6,960 \pm 350^{*}$ & $7.4 \pm 0.4$ \\
Periosteum-free calvaria & & & & $15.5 \pm 0.9$ \\
Control & $580 \pm 20$ & $3,420 \pm 330$ & $3,430 \pm 200$ & $23.0 \pm 0.7^{*}$ \\
bFGF & $1,770 \pm 200^{*}$ & $7,790 \pm 720^{*}$ & $4,790 \pm 330^{*}$ & \\
\hline
\end{tabular}

Values represent the effect of bFGF, $10 \mathrm{ng} / \mathrm{ml}$, on $\left[{ }^{3} \mathrm{H}\right]$ thymidine incorporation into acid-precipitable material (DNA) in calvariae cultured and treated for $24 \mathrm{~h}$, the effect of bFGF, $10 \mathrm{ng} / \mathrm{ml}$, on $\left[{ }^{3} \mathrm{H}\right.$ ]proline incorporation into CDP and NCP, and on the PCS in calvariae treated only for the first $24 \mathrm{~h}$ of a $72-\mathrm{h}$ culture. The periosteum was removed by dissection after the incubation was completed. Values are means \pm SE for six to eight half calvariae. * Significantly different from control, $P<0.05$.

the relative effect of bFGF was more pronounced in the periosteum than in the periosteum-free bone. Conversely, the labeling of CDP and the percentage of collagen synthesized were greater in the periosteum-free, osteoblast-rich bone, and the stimulatory effect of bFGF occurred primarily in this tissue (Table IV).

In contrast to the DNA synthesis-dependent stimulation of collagen synthesis observed after transient bFGF exposure, continuous treatment with bFGF decreased the incorporation of $\left[{ }^{3} \mathrm{H}\right]$ proline into CDP and the PCS (Fig. 3). The inhibitory effect of bFGF was selective for collagen, since it was observed in the absence of a significant decrease in NCP labeling and in the presence of a concomitant increase in $\left[{ }^{3} \mathrm{H}\right]$ thymidine incorporation into DNA. bFGF (100 ng/ml for $24 \mathrm{~h})$ inhibited collagen synthesis only in the periosteum-free bone, decreasing the incorporation of $\left[{ }^{3} \mathrm{H}\right]$ proline into CDP from a control value of $8,641 \pm 451$ to $6,232 \pm 597 \mathrm{dpm} /$ half calvaria (mean $\pm \mathrm{SE}, n=8, P<0.05$ ); this effect was limited to type I collagen as determined by polyacrylamide gel analysis (not shown). The stimulatory effect of bFGF on DNA labeling and the inhibitory effect on collagen synthesis were sustained after $96 \mathrm{~h}$ of continuous treatment (Fig. 4), but the effects were not related since hydroxyurea did not prevent the inhibitory effect of bFGF on collagen synthesis (not shown).

Collagen degradation rates, examined during a "pulse chase" experiment, were relatively small in control, and treated calvariae and were not affected by bFGF (Fig. 5).

Interactions with other agents. Heparin at $50 \mu \mathrm{g} / \mathrm{ml}$ had no effect on $\left[{ }^{3} \mathrm{H}\right]$ thymidine incorporation into DNA and slightly

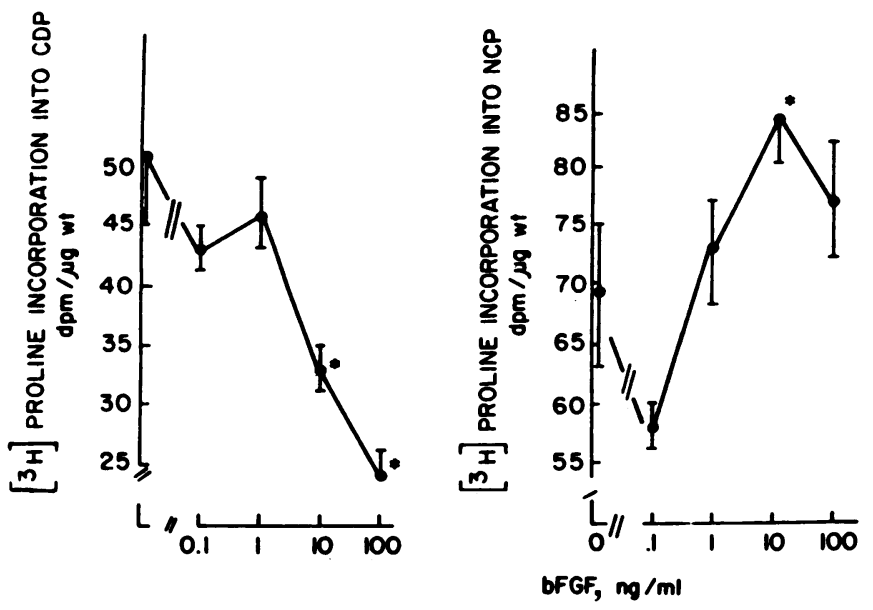

enhanced the stimulatory effect of bFGF (Table V). Conversely, heparin inhibited the incorporation of $\left[{ }^{3} \mathrm{H}\right]$ proline into CDP and was additive to the inhibitory effect of bFGF. Indomethacin at $1 \mu \mathrm{M}$, a dose shown to inhibit prostaglandin $\mathrm{E}_{2}$ synthesis in this culture model (10), did not modify the stimulatory effect of bFGF on DNA and NCP labeling, or its inhibitory effect on the incorporation of $\left[{ }^{3} \mathrm{H}\right]$ proline into CDP (data not shown).

\section{Discussion}

The present studies were undertaken to examine the effects of bFGF on bone formation in vitro. bFGF stimulated DNA synthesis in cultures of fetal rat calvariae since it increased the incorporation of $\left[{ }^{3} \mathrm{H}\right]$ thymidine into acid-precipitable material, the bone cell DNA content, and the number of colcemidinduced metaphase-arrested cells. Although the bFGF effect on DNA synthesis was primarily studied after $24 \mathrm{~h}$ of continuous treatment, the full effect was observed after a 2-h exposure to the growth factor. The stimulatory effect of bFGF on bone cell replication probably included osteoprogenitor cells, because it was greater in the periosteal layer, which is rich in this type of cells. Furthermore, the mitogenic effect resulted in an increased cell population capable of synthesizing type I collagen. Our observations indicate that bFGF stimulated the replication of osteoprogenitor cells which differentiated and manifested the osteoblastic phenotype. As a result of its mitogenic effect, bFGF also stimulated NCP synthesis, indicating that its actions were not specific for collagen. Although bone matrix

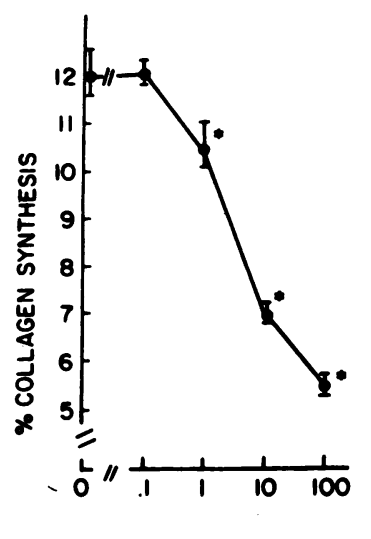

Figure 3. Effect of continuous treatment with bFGF on $\left[{ }^{3} \mathrm{H}\right]$ proline incorporation into $\mathrm{CDP}$ and $\mathrm{NCP}$, and on the PCS in cultured calvariae. Symbols and their vertical lines represent mean values and $\mathrm{SE}$ for six half calvariae cultured for $24 \mathrm{~h}$ in the continuous presence of bFGF. *Significantly different from control, $P<0.05$. 


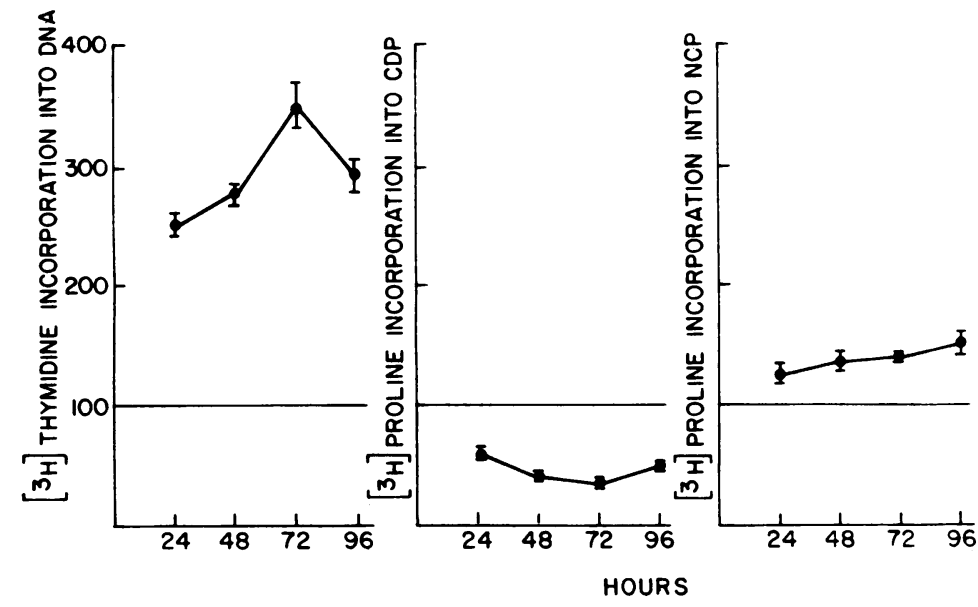

Figure 4. Effect of continuous treatment with bFGF, $100 \mathrm{ng} / \mathrm{ml}$, on $\left[{ }^{3} \mathrm{H}\right]$ thymidine incorporation into acid-precipitable material (DNA), on $\left[{ }^{3} \mathrm{H}\right]$ proline incorporation into CDP and NCP, and on the PCS. Calvariae were cultured in the continuous presence of $\mathrm{bFGF}, 100$ $\mathrm{ng} / \mathrm{ml}$, for the indicated periods of time. Data for the labeling of DNA, CDP, and NCP were corrected per bone dry weight (disintegrations per minute per weight); all data are expressed as percent of control. Symbols and their vertical lines represent mean values and SE for six half calvariae. All values for $b F G F$ are significantly different from control, $P<0.05$. contains bFGF (7), and bFGF increases a cell population capable of synthesizing bone collagen, we do not know if endogenous bFGF plays a physiological role in the local regulation of bone formation. This is in part because there is no information concerning the in situ availability of bioactive bFGF from bone matrix, and because bFGF may not be a secreted cell product (20).

The stimulatory effect of bFGF on osteoblastic collagen synthesis was indirect and secondary to its mitogenic effect. In addition, bFGF caused a direct inhibitory effect on osteoblastic function manifested by a decrease in type I collagen synthesis, when calvariae were continuously treated with the agent. This inhibitory effect of bFGF was selective for bone collagen synthesis, indicating that it was not due to a generalized toxic effect. The bFGF inhibition of collagen synthesis observed is in agreement with our previous report using native partially purified FGF (11). Since bFGF did not modify the rate of collagen degradation it is likely that its effects on collagen represent actual changes in collagen synthesis.

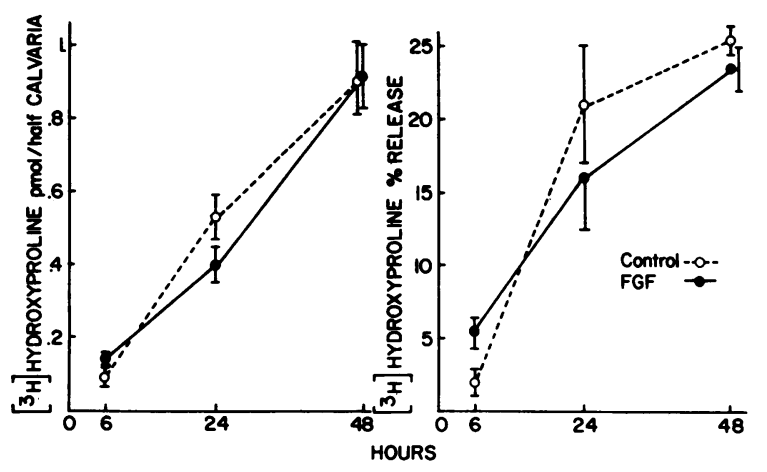

Figure 5. Effect of bFGF on collagen degradation. Calvariae were cultured in control medium for $24 \mathrm{~h}$ in the absence of unlabeled proline, and in the presence of $\left[{ }^{3} \mathrm{H}\right]$ proline $(5 \mu \mathrm{Ci} / \mathrm{ml})$, rinsed, and transferred to medium containing $10 \mathrm{mM}$ proline and "chased" in the presence ( $\bullet$ ) or absence (o) of bFGF, $100 \mathrm{ng} / \mathrm{ml}$, for the indicated periods of time. Symbols and their vertical lines represent means and SE for four half calvariae. Data are expressed as picomoles of total $\left[{ }^{3} \mathrm{H}\right]$ hydroxyproline released to the culture medium (left) or as the percent of the newly synthesized $\left[{ }^{3} \mathrm{H}\right]$ hydroxyproline released to the culture medium (right). None of the treated values was significantly different from control.
The stimulatory effects of bFGF on calvarial DNA and collagen synthesis are similar to those reported for ECGF, a form of aFGF (10). However, bFGF had a somewhat more pronounced effect on DNA synthesis than ECGF, and while heparin clearly enhanced the ECGF effect, it only caused a marginal enhancement of the bFGF effect on DNA synthesis. The similarity in the actions of bFGF and aFGF is not surprising because they have similar structures, analogous effects, and they bind to the same cell receptors in a variety of cell systems $(3,8,9,20)$. Conversely, heparin increases the affinity of aFGF to its receptor (21), and this does not seem to occur with bFGF. Although ECGF was shown to stimulate prostaglandin $\mathrm{E}_{2}$ synthesis, neither its effects nor those of bFGF could be attributed to prostaglandin production, since the response to these agents was not modified by indomethacin (10).

Since both aFGF and bFGF stimulate endothelial cell replication and neovascularization, they are possibly important for normal wound and bone repair. It has been postulated that de novo synthesis of bFGF does not occur as a result of tissue damage, which would cause the release or activation of stored bFGF (20). If this were the case, the function of bFGF stored in the bone matrix may be related to bone repair. In addition, FGFs have interactions with other local regulators of bone remodeling, such as transforming growth factor $\beta$, and may interact with systemic hormones (22). The effects of bFGF are not specific for skeletal cells, and it also has effects on myoblast function $(23,24)$, which could be important if bFGF contributes to the maintenance of skeletal mass. Recently, oncogenes have been characterized which possess extensive homologies to bFGF. In one instance, int- 2 has been reported to potentially function as a developmental control gene. Therefore, bFGF appears to play a diverse role in modulating the growth state of a variety of tissues (25). bFGF may be important in the pathophysiology of the skeletal changes observed in certain clinical conditions. For instance, prostatic tissue is rich in bFGF $(26,27)$, which could be responsible for the bone formation observed in the bone metastases of patients with prostatic carcinoma, although other factors may also be involved in this process (28).

In conclusion, bFGF stimulates bone cell replication, an effect that results in an increased number of collagen-synthesizing cells, but bFGF has a direct inhibitory effect on osteoblastic collagen synthesis in rat calvarial cultures. 
Table V. Effect of bFGF on DNA, Collagen, and NCP Synthesis Rates Studied in the Presence (+) and Absence (-) of Heparin in Calvariae Cultured for $24 \mathrm{~h}$

\begin{tabular}{|c|c|c|c|c|c|c|c|c|}
\hline \multirow[b]{2}{*}{ Treatment } & \multicolumn{2}{|c|}{ DNA } & \multicolumn{2}{|c|}{ CDP } & \multicolumn{2}{|c|}{ NCP } & \multicolumn{2}{|c|}{$\operatorname{PCS}(\%)$} \\
\hline & - Heparin & + Heparin & - Heparin & + Heparin & - Heparin & + Heparin & - Heparin & + Heparin \\
\hline & & & \multicolumn{2}{|c|}{$d p m / \mu g w t$} & & & & \\
\hline $\begin{array}{l}\text { Control } \\
\text { bFGF }\end{array}$ & $3.3 \pm 0.1$ & $3.2 \pm 0.2$ & $54 \pm 3$ & $35 \pm 2$ & $76 \pm 3$ & $66 \pm 3$ & $11.6 \pm 0.7$ & $9.0 \pm 0.4$ \\
\hline $0.1 \mathrm{ng} / \mathrm{ml}$ & $3.9 \pm 0.1^{*}$ & $4.0 \pm 0.3^{*}$ & $40 \pm 4^{*}$ & $26 \pm 3^{* *}$ & $76 \pm 6$ & $62 \pm 3$ & $8.8 \pm 0.4^{*}$ & $7.2 \pm 0.9^{*}$ \\
\hline $1 \mathrm{ng} / \mathrm{ml}$ & $6.0 \pm 0.5^{*}$ & $8.4 \pm 0.3^{* \ddagger}$ & $39 \pm 3^{*}$ & $25 \pm 2^{* \neq}$ & $82 \pm 4$ & $71 \pm 5$ & $8.1 \pm 0.4^{*}$ & $6.1 \pm 0.3^{* \neq}$ \\
\hline $10 \mathrm{ng} / \mathrm{ml}$ & $10.0 \pm 0.6^{*}$ & $12.3 \pm 0.3^{* \ddagger}$ & $29 \pm 2^{*}$ & $20 \pm 2^{* \pm}$ & $88 \pm 3^{*}$ & $103 \pm 4^{* \neq}$ & $5.8 \pm 0.3^{*}$ & $3.4 \pm 0.3^{* \neq}$ \\
\hline $100 \mathrm{ng} / \mathrm{ml}$ & $11.3 \pm 0.3^{*}$ & $11.4 \pm 0.3^{*}$ & $31 \pm 3^{*}$ & $15 \pm 1^{* \neq}$ & $112 \pm 7^{*}$ & $102 \pm 5^{*}$ & $5.0 \pm 0.6^{*}$ & $2.6 \pm 0.1^{* \neq}$ \\
\hline
\end{tabular}

Values represent the effect of bFGF with $(+)$ and without $(-)$ heparin, $50 \mu \mathrm{g} / \mathrm{ml}$, on $\left[{ }^{3} \mathrm{H}\right]$ thymidine incorporation into acid-precipitable material (DNA) on $\left[{ }^{3} \mathrm{H}\right]$ proline incorporation into CDP and NCP, and on the PCS in calvariae cultured and treated for $24 \mathrm{~h}$. Values are means \pm SE for five half calvariae. * Significantly different from respective control, $P<0.05$. ${ }^{\ddagger}$ Significantly different from $b F G F$ alone, $P<0.05$.

\section{Acknowledgments}

The authors thank Miss Sandra Casinghino, Mrs. Bari Gabbitas, and Mrs. Sheila Rydziel for expert technical assistance, and Mrs. Nancy Brignoli for valuable secretarial help.

This work was supported by grant AR21707 from the National Institute of Arthritis and Musculoskeletal and Skin Diseases.

\section{References}

1. James, R., and R. A. Bradshaw. 1984. Polypeptide growth factors. Annu. Rev. Biochem. 53:259-292.

2. Butgess, W. H., T. Mehlman, R. Freisel, W. V. Johnson, and T. Maciag. 1985. Multiple forms of endothelial cell growth factor. J. Biol. Chem. 260:11389-11392.

3. Esch, F., A. Baird, N. Ling, N. Ueno, F. Hill, L. Denoroy, R. Klepper, D. Gospodarowicz, P. Bohlen, and R. Guillemin. 1985. Primary structure of bovine pituitary basic fibroblast growth factor (FGF) and comparison with the amino-terminal sequence of bovine braip acidic FGF. Proc. Natl. Acad. Sci. USA. 82:6507-6511.

4. Gospodarowicz, D., G. Neufeld, and L. Schweigerer. 1986. Fibroblast growth factor. Mol. Cell Endocrinol. 46:187-204.

5. Moscatelli, D., M. Presta, J. Joseph-Silverstein, and D. B. Rifkin. 1986. Both normal and tumor cells produce basic fibroblast growth factor. J. Cell Physiol. 129:273-276.

6. Klagsbrun, M., J. Sasse, R. Sullivan, and J. A. Smith. 1986. Human tumor cells synthesize an endothelial cell growth factor that is structurally related to basic fibroblast growth factor. Proc. Natl. Acad. Sci. USA. 83:2448-2452.

7. Hauschka, P. V., A. E. Maurakos, M. D. Iafrati, S. E. Doleman, and M. Klagsbrun. 1986. Growth factors in bone matrix. J. Biol. Chem. 261:12665-12674.

8. Gimenex-Gallego, G., G. Conn, V. B. Hatcher, and K. A. Thomas. 1986. Human brain-derived acidic and basic fibroblast growth factors: amino terminal sequences and specific mitogenic activities. Biochem. Biophys. Res. Commun. 135:541-548.

9. Neufeld, G., and D. Gospodarowicz. 1986. Basic and acidic fibroblast growth factors interact with the same cell surface receptors. J. Biol. Chem. 261:5631-5637.

10. Canalis, E., J. Lorenzo, W. Burgess, and T. Maciag. 1987. Effects of endothelial cell growth factor on bone remodeling in vitro. $J$. Clin. Invest. 79:52-58.

11. Canalis, E., and L. G. Raisz. 1980. Effect of fibroblast growth factor on cultured fetal rat calvaria. Metab. Clin. Exp. 29:108-114.

12. Montesano, R., J.-D. Vassalli, A. Baird, R. Guillemin, and L. Orci. 1986. Basic fibroblast growth factor induces angiogenesis in vitro. Proc. Natl. Acad. Sci. USA. 83:7297-7301.

13. Canalis, E. 1980. Effect of insulin-like growth factor I on DNA and protein synthesis in cultured rat calvaria. J. Clin. Invest. 66:709719.
14. Kissane, J. M., and E. Robbins. 1958. The fluorometric measurement of deoxyribonucleic acid in animal tissues with special reference to the central nervous system. J. Biol. Chem. 233:184-188.

15. Peterkofsky, B., and R. Diegelmann. 1971. Use of a mixture of proteinase-free collagenases for the specific assay of radioactive collagen in the presence of other proteins. Biochemistry. 10:988-993.

16. Peterkofsky, B. 1972. The effect of ascorbic acid on collagen polypeptide synthesis and proline hydroxylation during the growth of cultured fibroblasts. Arch. Biochem. Biophys. 152:318-328.

17. Sykes, B., B. Puddle, M. Francis, and R. Smith. 1976. The estimate of two collagens from human dermis by interrupted gel electrophoresis. Biochem. Biophys. Res. Commun. 72:1472-1480.

18. Peck, W. A., S. J. Birge, and S. A. Fedak. 1964. Bone cells: biochemical and biological studies after enzymatic isolation. Science (Wash. DC). 146:1476-1477.

19. Wong, G. L., and D. V. Cohn. 1975. Target cells in bone for parathormone and calcitonin are different. Enrichment for each cell type by sequential digestion of mouse calvaria and selective adhesion to polymeric surfaces. Proc. Natl. Acad. Sci. USA. 72:3167-3171.

20. Abraham, J. A., J. L. Whang, A. Tumolo, A. Mergia, J. Friedman, D. Gospodarowicz, and J. C. Fiddes. 1986. Human basic fibroblast growth factors: nucleotide sequence and genomic organization. EMBO (Eur. Mol. Biol. Organ.) J. 5:2523-2528.

21. Schreiber, A. B., J. Kenney, W. J. Kowalski, R. Friesel, T. Mehlman, and T. Maciag. 1985. Interaction of endothelial cell growth factor with heparin: characterization by receptor and antibody recognition. Proc. Natl. Acad. Sci. USA. 82:6138-6142.

22. Centrella, M., T. McCarthy, and E. Canalis. 1987. Mitogenesis in fetal rat bone cells simultaneously exposed to transforming growth factor $\beta$ and other growth regulators. FASEB (Fed. Am. Soc. Exp. Biol.) J. 1:312-317.

23. Olwin, B. B., and S. D. Hauschka. 1986. Identification of the fibroblast growth factor receptor of SWISS 3T3 cells and mouse skeletal muscle myoblasts. Biochemistry. 25:3487-3492.

24. Spizz, G., D. Roman, A. Strauss, and E. N. Olson. 1986. Serum and fibroblast growth factor inhibit myogenic differentiation through a mechanism dependent on protein synthesis and independent of cell proliferation. J. Biol. Chem. 261:9483-9488.

25. Marx, J. L. 1987. Oncogene action probed research news reported. Science (Wash. DC). 237:602-603.

26. Story, M. T., F. Esch, S. Shimasaki, J. Sasse, S. C. Jacobs, and R. K. Lawson. 1987. Amino-terminal sequence of a large form of basic fibroblast growth factor isolated from human benign prostatic hyperplastic tissue. Biochem. Biophys. Res. Commun. 142:702-709.

27. Story, M. T., J. Sasse, S. C. Jacobs, and R. K. Lawson. 1987. Prostatic growth factor: purification and structural relationship to basic fibroblast growth factor. Biochemistry. 26:3843-3849.

28. Koutsilieris, M., S. A. Rabbani, H. P. J. Bennett, and D. Goltzman. 1987. Characteristics of prostate-derived growth factors for cells of the osteoblast phenotype. J. Clin. Invest. 80:941-946. 